\title{
Linking, leveraging and learning: sectoral systems of innovation and technological catch-up in China's commercial aerospace industry
}

\author{
David J. Smith^ and Michael Zhang \\ Nottingham Business School, \\ Nottingham Trent University, \\ Burton Street, Nottingham NG1 4BU, UK \\ E-mail: david.smith02@ntu.ac.uk \\ E-mail: michael.zhang@ntu.ac.uk \\ *Corresponding author
}

\begin{abstract}
Developing countries often have ambitions to become major players in the commercial aerospace industry, but it remains effectively a duopoly dominated by Boeing of the USA and Europe's Airbus. China is no exception and the projects designed to bring this about have taken a number of forms. Adopting the sectoral system of innovation (SSI) as an analytical framework, this paper explores recent changes in the industry. Using China's ARJ21 regional jet programme as a case study, it examines how these changes provide opportunities for latecomer nations to catch-up technologically. It is argued that the new institutional context and the presence of new actors within the SSI, represent an opportunity for latecomer nations like China to acquire the capability to design, develop and manufacture commercial jet airliners, through linking with Western suppliers. However the analysis reveals that as a latecomer nation, China may prove to be a special case, with the opportunities for catch-up by other latecomers much more limited.
\end{abstract}

Keywords: co-evolution; innovation; technological catch-up; sectoral system of innovation; SSI; aerospace; China.

Reference to this paper should be made as follows: Smith, D.J. and Zhang, M. (2014) 'Linking, leveraging and learning: sectoral systems of innovation and technological catch-up in China's commercial aerospace industry', Global Business and Economics Review, Vol. 16, No. 4, pp.349-368.

Biographical notes: David Smith received his degree in Economics from Lancaster University in 1973 and his PhD from Nottingham University in 1985. He is currently a Professor of Innovation Management at Nottingham Business School. Prior to this, he was a Reader in Strategic Management at Northampton University. His research interests include innovation, improvisation, technical entrepreneurship, R\&D partnerships, supply chain management and the aerospace industry.

Michael Zhang obtained his PhD from Sheffield University in 2000. He is currently a Reader in International Strategy at Nottingham Business School. Prior to this, he was a Senior Research Fellow at Manchester Metropolitan University carrying out research as part of an ESRC research project: RES334-25-0015 Evolution of Business Knowledge in SMEs. His current research interests include economic development and market process, technology analysis and entrepreneurship and corporate sustainability and organisational learning. 


\section{Introduction}

Despite the dominance of the Americans (Newhouse, 2007) and latterly the Europeans, several Asian countries have long aspired to catch-up and join the 'big boys' in commercial aerospace production. The strength of these ambitions is well illustrated by Samuels (1994, p.210) who notes how the position of the Japanese is expressed by the view that, 'a nation without an aircraft industry will never pass as an industrial nation of the first rank'. However the Asian aerospace industry is, 'an elephants' graveyard' (Bitzinger, 2010), littered with the bones of commercial aircraft projects that carried these aspirations but failed to deliver.

Among the most ambitious Asian nations was Indonesia, whose state-owned Industri Pesawat Terbang Nusantara (IPTN) led by Research and Technology Minister, B.J. Habibie, poured millions of dollars in the 1990s into the development of an advanced turboprop airliner the $\mathrm{N}-250$ and the $\mathrm{N}-2130$ a 100 seat regional jet. Both fell victim to the Asian financial crisis of the late 1990s. South Korea's attempts at catch-up were also stillborn. The AE-100 Air Express, another 100 seat regional jet project, was a collaborative project involving Samsung, Hyundai, Daewoo and Korean Air (Steenhuis et al., 2007) together with other Asian partners, but it too foundered in the mid-1990s, mainly because of disagreement on the location of the final assembly line (Lewis, 1995a, 1996). Even Japan has so far failed despite repeated attempts. In the 1970s a consortium comprising Mitsubishi, Kawasaki and Fuji, developed the YS-11, a 60 seat turboprop airliner. But though technically sound, it was not a commercial success. A succession of projected jet airliner projects followed, including the 200 seat YX jet, the smaller 150 seat YXX jet and later stills the even more modest YSX-100 60 seat regional jet. However none got beyond the drawing board. More recently Mitsubishi has launched a new regional jet, the MRJ-70, which is in the early stages of development.

Finally China has over the last 30 years made several attempts at catch-up in order to develop a modern commercial airliner. The most recent of these is the current ARJ21 project to develop a 100 seat regional jet. Now nearing final certification, this paper uses the ARJ21 programme as a case study in order to analyse China's catch-up attempts. The case itself is derived from archival materials, specifically documentary sources in the form of specialist aviation periodicals, including Flight International, Aviation Week and Space Technology, American Aerospace, Air Transport World and the Aeronautical Journal, supplemented by specialist reports into the aerospace industry provided by the Financial Times, the RAND Corporation and the US International Trade Commission, together with additional quantitative data from Boeing's Market Forecasts. The case advances the proposition that fundamental changes in the sectoral system of innovation (SSI) for commercial aerospace, have for the first time raised the prospect that China as a latecomer nation may be about to succeed in its ambition to catch-up and become a player in the commercial airliner market.

\section{Theoretical framework: SSI}

The systems of innovation approach operates on a number of levels. Where SSI are concerned the focus is on a particular technological field or product area (Edquist, 2001). An SSI is typically defined as a group of firms active in developing and making a sector's products and in generating and using a sector's technologies (Breschi and Malerba, 1997; 
Geels, 2004). As such SSI focus on a range of factors that contribute both directly and indirectly to the production of innovations within a particular sector (Hekkert et al., 2007). The concept of an SSI came about as a result of dissatisfaction with earlier theoretical approaches such as those used in industrial economics that focused more narrowly on things like R\&D intensity and patent activity (Malerba, 2005). Such perspectives it is argued are too simplistic and fail to take account of the range of factors that are relevant when it comes to explaining differences in innovation across sectors. The SSI perspective in contrast, recognises that innovation is likely to be organised and carried out very differently across industry sectors, even if they share the same level of advanced technology.

According to Malerba (2004) SSI comprise three main building blocks: the knowledge/technology base; actors and their networks; and institutions, all of which interact in the development of new products and innovations. Of the three, knowledge/technology plays a central role, as it is the knowledge/technology base that differentiates and de-limits particular sectors (Edquist, 2001). The nature of the knowledge/technology base is also likely to be highly influential in terms of both the nature and organisation of innovation. Sources of knowledge too are likely to differ by sector (Malerba, 2006). Thus in some sectors scientific advances and breakthroughs will be a key input to innovation, while in others advances in R\&D may be critical and in yet other sectors it may be users who are the main source of knowledge (Malerba and Mani, 2009). Similarly the scope of the knowledge base can be influential. If advanced integration capabilities are important the sector may be concentrated into a few large firms, while if knowledge is easily accessible innovation may be undertaken by small firms.

The actors are firms who may be individuals, groups and organisations. They comprise not only innovators themselves but suppliers, customers and competitors, as well as bodies such as universities, venture capitalists and innovation policy agencies (Edquist and Johnson, 1997). It is the actors who initiate and carry out the activities associated with the development of new products (Edquist, 2001). Since actors do not generally undertake innovation in isolation (Edquist, 2001), the development of new products typically involves intense interaction between actors and the knowledge base, and it is through this interaction that learning, a vital part of innovation, occurs (Zhang et al., 2006).

In all sectoral systems, institutions play a major role in terms of the organisation of innovative activity (Malerba, 2006). Some institutions are national or even international while others are purely sectoral. A key feature of institutions of whatever type is the way in which, either directly or indirectly, they provide the 'incentive' framework, or to use North's (1990, p.3) terminology 'the rules of the game', that act as a driver to individuals, groups and organisations to initiate and undertake innovation. Such rules take the form of sets of routines, established practices, rules and regulations that serve to regulate the relations and interactions between the actors in the SSI. In this way they shape the actions of the actors in an SSI and relations between them.

Malerba (2005, p.381) reminds us that there is 'a rich and heterogeneous tradition' of studies of SSI which clearly show not only that the knowledge/technology base, the actors involved in innovation and the links between them and the relevant institutional context, are crucial factors when it comes to understanding and explaining the process of innovation, but also that these factors differ significantly from sector to 
sector. Hence sectors may be highly innovative and technologically advanced with strong links to science, but the process of innovation may be organised very differently within them.

This helps to explain why, where latecomer nations are concerned, though the technological catch-up process may be relatively straightforward in some sectors, it can be highly problematic in others, making it almost impossible for new entrants to gain a foothold within a sector. Thus in sectors like electronics and automotive products for example, entry into the sector has proved feasible for latecomer nations like Brazil, South Korea and Malaysia, largely because the innovation process is well understood and the SSI does not present hurdles that are impossible to surmount. In other sectors however it is a different story, here the nature of the SSI can at times make it very difficult, even for ambitious and well resourced latecomer nations, to catch-up and successfully break into the sector.

Sectoral systems are not static, they can and do change and transform over time. In theoretical terms the SSI concept is grounded in evolutionary theory. Single elements such as actors do not merely evolve in isolation (Lewin and Volderba, 1999). Rather as Malerba and Mani (2009) point out they co-evolve with other elements, in this instance the knowledge/technology base and the institutional context, as part of a process of co-evolution. Hence co-evolutionary effects result in changes in one element of the SSI interacting with changes in other elements to induce further changes. Changes in the knowledge/technology base for instance can induce major changes in the structure and behaviour of actors (i.e., firms). With co-evolution, change does not only come about through direct interaction. As Lewin and Volderba (1999) note, change can also be recursive, being driven by feedback from the rest of the system.

The effect of changes resulting from co-evolution is to alter the characteristics of the SSI, leading to a situation where the innovation process is organised differently. Many sectors have seen such changes. Malerba (2005) notes that the computer sector has been subject to co-evolutionary processes, leading to a move away from a highly concentrated structure where large vertically integrated firms played a dominant role in the innovation process, in favour of a structure where interdependencies and externalities are important.

It is against this background that this study focuses on an industry sector which with one or two exceptions (Marques and de Oliveira, 2009) has been almost entirely neglected by researchers of SSI (McGuire, 1999). And yet, as several observers have noted the aerospace sector has been subject in recent years to a number of very significant changes in its SSI (Lorrell et al., 2000). In the light of this, this study utilises the concept of SSI as a theoretical framework, in order to answer two principal research questions:

1 What have been the main changes in this sector's SSI?

2 What are the implications of these changes for latecomer nations seeking to catch-up?

It does this by utilising the development of China's ARJ21 regional jet programme as a case study. 


\section{The evolution of the SSI for commercial aerospace}

\subsection{The integrated SSI}

Until the 1990s the SSI for commercial aerospace was very like the innovation system that prevailed in the computer industry in the 1960s and 1970s, which was dominated by vertically integrated companies such as IBM that produced complete computer systems. In terms of innovation and new product development these vertically integrated computer companies with their extensive research and development facilities undertook the design, development, manufacturing, marketing and distribution of complete mainframe computer systems utilising components they produced (Malerba, 2005).

Since it was also a relatively new high tech industry, the system of innovation in the commercial aerospace industry closely resembled the SSI of the early computer industry at this time. Key features of the aerospace SSI were large vertically integrated firms who formed the principal actors, powerful regulatory institutions that controlled the market and a narrowly defined technology base. The actors were large airframe manufacturers like Boeing and Lockheed (Lawrence and Thornton, 2005; Newhouse, 2007; Nolan et al., 2008), that possessed an extensive range of capabilities that enabled them to design, develop and manufacture most of the principal systems of a commercial airliner. The institutions included a range of regulatory bodies such as the Civil Aeronautics Board (CAB) which controlled most aspects of the world's largest aircraft market (Heppenheimer, 1995), the US, IATA the international airline cartel that fixed airline fares worldwide and the Federal Aviation Administration (FAA) which had oversight of safety standards in the US where most aircraft were built. National governments too were important institutions since many airlines were state owned and heavily subsidised (Lorrell et al., 2000). The technology base was narrowly drawn being confined to mechanical technologies associated with aerodynamics, aero-structures and hydraulics. Significantly military and commercial technologies were largely interchangeable providing scope for extensive cross subsidisation (Lawrence and Thornton, 2005; Rogers, 1996).

These elements taken together comprised an SSI that emphasised technical excellence rather than competitive forces such as costs. Innovation and new product development were carried out on an integrated basis by vertically integrated airframe manufacturers with the capability to develop and produce the full range of aircraft systems, apart from engines. The world's best-selling airliner of the period for instance, Boeing's 727 tri-jet, had just 2\% foreign content (Macpherson and Pritchard, 2007).

\subsection{Co-evolution and the network SSI}

Although this integrated system of innovation prevailed for several decades, since the 1980s co-evolution of the various elements that make up the system has brought significant change and transformation to the innovation and new product development process for commercial aerospace.

\subsubsection{Actors}

In the last 30 years new actors have appeared in the aerospace SSI, in particular a group of highly capable global suppliers, has emerged alongside the airframe manufacturers as 
important contributors to the aerospace innovation process. A key factor in their expanding role has been the increasingly modular nature of modern airliners reflecting a trend seen in other sectors such as the automotive industry. Faced with the problem of trying to span an ever greater range of technologies in developing modern airliners, airframe manufacturers have relinquished responsibility for the development and manufacture of many of the larger modules and sub-systems such as wings, fuselage barrels, landing gear and avionics (Cooke and Ehret, 2009; Ehret and Cooke, 2010). Instead these modules are increasingly designed, developed and manufactured by specialist suppliers who not only undertake manufacturing but extensive research and development (McGuire et al., 2010; Smith and Tranfield, 2005). These specialist suppliers are much more than mere subcontractors called upon to manufacture components on a 'build-to-print' basis (Smith and Tranfield, 2005). They have a significant level of capability especially with regard to research and development. Many are substantial multinational corporations in their own right (Bédier et al., 2008; McGuire et al., 2010) and these days they make an important contribution to all new commercial airliner development programmes.

\subsubsection{Technology base}

The technology base evolved as new technologies have been embraced by aerospace engineers. As a result commercial aerospace evolved from a narrow technology base involving a limited range of technologies to a multi-technology industry (Benzler and Wink, 2010; McGuire et al., 2010). One of the biggest changes was the application of digital electronics which gave rise to fly-by-wire (FBW) technology which transformed the control systems of a modern airliner (Langeweische, 2009). Thus digital electronics and software became major technologies in aerospace. More recently composite materials have become much more widely used even for relatively large aero-structures such as wings and fuselage sections. At the same time military and civil aerospace technologies, which were once almost identical, have diverged to the point where there is now rarely scope for cross-subsidising the development of new civil airliner projects through the use of military designed technologies (McGuire et al., 2010). Hence large commercial aircraft now utilise a multiplicity of advanced technologies (Nolan et al., 2008), beyond the scope of a single firm.

\subsubsection{Institutional framework}

The institutional framework of commercial aerospace has also evolved. Since the 1980s de-regulation has swept through the airline industry. In the USA, the CAB was abolished opening the world's largest market to new entrants. It was followed by similar de-regulation across Europe and Asia. At the same time the ending of IATA's role in price fixing brought the demise of many well known airline names, and more significantly a shift from service competition to intense price competition. Fuelled further by privatisation and a decline in state subsidies, the airlines became much more price sensitive and pre-occupied with costs (Lorrell et al., 2000; Sampson, 1984). Alongside these institutional changes which have affected the macro-environment of the industry have come micro level changes affecting firms. These have centred on inter-organisational arrangements in the form of partnerships between airframe 
manufacturers and their suppliers to create global production networks (Dicken, 2011). These enable suppliers to take a more active part in new product development.

\subsection{Co-evolution}

Not only have the changes in each of the three elements: actors, technology base and institutional framework, had an impact in themselves, they have affected the other elements through a process of co-evolution. Thus institutional changes like the abolition of the $\mathrm{CAB}$ and the reduction in the power of IATA have resulted in much more competitive conditions, which have in turn led airframe manufacturers to outsource many of their functions, a trend that has also been stimulated by increased modularity and the number of technologies used in modern aircraft. The move to a multi-technology environment encouraged the growth of global suppliers specialising in particular aircraft modules and sub-systems, which in turn led to the increased use of risk and revenue sharing partnerships. Added together the combined effect of these changes has been to move to a network SSI, where new product development no longer takes place on an integrated basis involving a single firm, but is rather the product of a partnership between several firms.

Under this new system, airframe manufacturers like Boeing, act as the lead or flagship firm, serving as systems integrator, assembling modules and sub-systems built by suppliers working not as subcontractors but as partners (Dunne, 1999). As systems integrators they have overall responsibility for design, assembly and marketing the complete aircraft. This has allowed the airframe manufacturers to accelerate the innovation process, thereby reducing lead times, spreading risk and sharing development costs while also learning from suppliers (Nolan and Zhang, 2003).

In many respects Airbus ushered in the network SSI by pioneering aircraft manufacture based on the final assembly of large sub-systems designed, developed and manufactured by partners in the European consortium (Cooke and Ehret, 2009; Nolan et al., 2008). However in the 1990s Boeing too moved towards a network approach for developing new aircraft, when it granted three Japanese firms a $21 \%$ stake in the development of its new Boeing 777 airliner [Kimura, (2007), p.150; Sabbagh, (1996), p.67], a move that brought Japanese firms to the heart of the innovation process as members of Boeing's design team. Nor was this confined to developed countries. In Brazil the aerospace firm Embraer (Pritchard and MacPherson, 2007) was one of the first to take advantage of opportunities created by the emergence of the new network SSI. In the mid-1990s Embraer, took the bold step to develop a 50 seat regional jet using a risk and revenue sharing partnership comprising a network of foreign suppliers (Figuieredo et al., 2008; Goldstein, 2002). A derivative (Smith and Rogers, 2004) of its existing 30 seat turboprop design with which it retained 30\% commonality [Goldstein and Le Blanc, (2003), p.10] the production network involved wings built in Spain, landing gear in Germany, rear fuselage in Belgium and engines in the USA, with foreign firms contributed some 55\% of the value of each aircraft [Goldstein and LeBlanc, (2003), p.13]. Utilising a network approach to new product development in this way was a key factor in the success of the ERJ-145, 1000 of which were sold in the ten years to 2007 [Goldstein, (2008), p.58; Marques and de Oliveira, (2009), p.169], as Embrear's turnover increased from US\$0.29 billion in 1996 to US\$4.6 billion in 2005 [Marques and de Oliveira, (2009), p.173)]. 
Thus as the examples of Boeing and Embraer make clear, by the decade of the 2000s, in the commercial aerospace sector the innovation process, by which new products are developed, had been transformed as aerospace firms moved from an integrated SSI to a network SSI. This came about not merely because the technology evolved over time but through a complex process of co-evolution that embraced changes in the technology base, the actors and the institutional framework. While new airliner programmes are today launched by a single prime contractor like Boeing, who oversees the overall design, assembly and marketing of the aircraft, they rely on a network of specialist suppliers for the design, development and manufacture of major modules and sub-systems. Hence the innovation process in the commercial aerospace sector is now best described as a network SSI.

\section{Case study: the ARJ21 regional jet programme}

\subsection{Earlier attempts at catch-up}

The origins of China's aerospace industry lie in the Sino-Soviet pact signed during the Korean War in 1953, under the terms of which, Soviet military aircraft were built under licence in Shenyang and Harbin in North East China in factories constructed during the Japanese occupation of the 1930s (Heymann, 1975). The limitations of this became apparent with the break-up of the pact in August 1960 and the withdrawal of Soviet personnel. The Soviet 'arm's length' approach to technology transfer which was limited to the transmission of technical data (Heymann, 1975), meant Chinese engineers, 'had no background design and development experience on which to draw' [Hooker, (1984), p.213].

Unable to purchase Russian aircraft, the Chinese looked to the capitalist West and in 1963, despite a US embargo bought six British Viscount 843 airliners (Engel, 2007), followed in the early 1970s by 35 British Trident airliners and ten American Boeing 707 airliners. The Chinese also negotiated licensed production of Rolls-Royce Spey engines to be produced in Xian (Johnson, 1992). Having acquired modern Western airliners the Chinese then embarked on a plan to develop an indigenous airliner of their own, the Y-10, a reverse-engineered Boeing 707. Spearheaded by Wang Hongwen, one of the 'Gang of Four', it was designed and built by the Shanghai Aircraft Manufacturing Company (SAMC) and first flew in September 1980 (Cantle, 2008). However so poor was its performance that it was quietly abandoned five years later when only two aircraft had been built.

By the time the Maoist era drew to a close, the Chinese had built up an aerospace industry, but with the exception of the link to Britain's Rolls-Royce, it was still wedded to out-dated Soviet technology (Dougan, 2002; Todd and Simpson, 1985).

\subsection{The co-production era of the 1980s and 1990s}

In the post-Mao era of economic reform, China's ambitions for developing commercial aerospace became clearer. One strand of development involved the production of small less sophisticated civil aircraft, such as the 50 seat Y-7 turboprop airliner developed from the Russian Antonov An-24 (Dougan, 2002; Lewis, 1997). This project, like similar ones, did not meet with commercial success (Goldstein, 2006). Alongside these attempts at 
small scale indigenous production, China mounted a serious effort to catch-up in the commercial aerospace market, by leveraging technological capabilities through cooperation with Western aircraft manufacturers (Nolan and Zhang, 2002, 2003). In particular China sought to co-produce a new generation of modern commercial airliners, as the first step in a 'three step plan' [Dougan, (2002), p.106], designed to enable the country to progressively catch up in terms of technological capabilities. The steps in this process were:

1 cooperate with a foreign partner to co-produce a medium-sized civil airliner within China

2 with a foreign partner jointly design and manufacture a 100 seat regional jet in China

3 by 2010 have amassed the relevant technologies to provide a capability to design and build a medium-sized 180 seat airliner independently.

As a first step, co-production not only offered an opportunity for including significant local content, it also offered scope for learning Western production methods.

The strategy was initiated with an agreement in April 1985, following six years of protracted negotiation, with McDonnell-Douglas of the US for the co-production of the MD-80 airliner. The agreement was for Shanghai Aviation Industrial Corporation (SAIC) to co-produce twenty-five (25) 170 seat MD-80 airliners intended for domestic use in China. 15-20\% local content was planned (Steenhuis and De Bruijn, 2004) initially. The first aircraft flew in 1987 with the first delivery in the same year (Andersen, 2008). Over the next eight years a total of 35 MD-82 and MD-83 jet airliners were assembled by SAIC [Goldstein, (2006), p.261], though the local content never approached the $75 \%$ planned [Goldstein, (2008), p.60].

A more ambitious follow-on agreement, signed by Aviation Industries of China (AVIC) in 1992 and intended as the second step in the three stage plan, was for the joint development of a new and more advanced version of the MD-82, the MD-90 'Trunkliner' to be followed in time by a 100 seat regional jet version, the MD-95. A total of 150 Trunkliners were planned [Dougan, (2002), p.107]. Assembly was to be carried out by SAIC in Shanghai, with $75 \%$ of the fabrication undertaken in China, including construction of the wings and forward fuselage in Xian, the nose in Chengdu and the empennage and electrical work in Shenyang (Lewis, 1997). However the Asian economic crisis of the late 1990s (McGuire, 1999), combined with the resistance of China's Civil Aviation Administration and Boeing's takeover of McDonnell-Douglas in 1996, eventually brought cancellation of the Trunkliner programme, with only two aircraft completed (Goldstein, 2006).

Attempts to put in place alternative arrangements to implement the second step of China's catch-up plan, this time involving the joint design and manufacture of a regional jet in collaboration with a foreign partner, were however to prove both frustrating and protracted. In 1994 the Chinese signed a memorandum of understanding with South Korea to develop the Air Express AE-100 regional jet (Lewis, 1995b; Steenhuis et al., 2007). But difficulties in reaching agreement about each country's role in the project led to the eventual withdrawal of the Koreans from the project in 1996 before a Western partner had been found.

Undaunted, the Chinese pressed on and eventually found a Western partner in Aero International (Regional) (AI(R)), a European consortium comprising France's Aerospatiale, Italy's Alenia, and British Aerospace. The inclusion of Aerospatiale and 
British Aerospace was significant, since both were part of the Airbus consortium and early in 1997 Airbus itself duly joined the project along with Singapore Technologies. Thus was born a new incarnation of China's proposed regional jet, this time designated the AE-31X. Unfortunately China's insistence on responsibility for systems integration, a capability it as yet clearly lacked, combined with a re-appraisal of the regional jet market by Airbus, who in the end decided to go it alone developing the A318 a 100 seat version of its highly successful A320 airliner, eventually led to this project also foundering in 1998.

\subsection{The ARJ 21 regional jet}

Thwarted in their numerous attempts to find a foreign partner with whom they could co-develop a regional jet on terms that would provide appropriate opportunities for technological upgrading and enhancement, the Chinese eventually abandoned the search for a Western partner. Instead in June 2002 the ARJ21 regional jet, known as the 'Xiang Feng - the Flying Phoenix' (Anderlini, 2008), was launched. This time a very different development model was used. Based on the new network SSI, a partnership with a Western airframe manufacturer was replaced with a network of specialist global suppliers who provided a wide range of aircraft systems.

The ARJ21 is a 90 seat regional jet, being developed as part of China's 11th Five Year Plan (Endres, 2007), by Comac a government controlled consortium. This comprises the leading state-owned aircraft manufacturing plants, including those in Shanghai, Xian, Chengdu and Shenyang, long associated with aircraft manufacturing in China. Although Shanghai Aviation Industry Corporation (SAIC) is undertaking final assembly at its plant in Shanghai, Table 1 shows that other members of the consortium are being used to develop and manufacture major parts of the airframe.

Table 1 Comac ARJ21Airframe Development and Production Responsibilities

\begin{tabular}{llc}
\hline & Company & Sub-system responsibility \\
\hline 1 & Chengdu Aircraft Company (CAC) & Nose \\
2 & Shanghai Aircraft Industry Company (SAIC) & Horizontal stabiliser \\
3 & Shenyang Aircraft Corporation (SAC) & Vertical stabiliser, engine pylons, electrical \\
& & sub-assembly \\
4 & Xian Aircraft Company (XAC) & Wing, centre fuselage \\
\hline
\end{tabular}

Source: Balut et al. (2008, p.3)

As well as being the second stage of the three step catch-up plan that the Chinese embarked upon back in the 1980s, the decision to develop a regional jet was underpinned by two factors. Firstly the Chinese government hoped that the use of regional jets would rapidly expand during the decade of the 2000s (Sobie, 2003) mirroring the rapid growth in the use of regional jets that occurred in the US in the 1990s (Smith, 2003). Secondly it hoped that a regional jet capable of operating in high and hot conditions from short runways, would help to open up domestic air links with the country's remote and underdeveloped western provinces (Cantle, 2008), thereby bringing these relatively backward regions into the 21st century (Sweeney, 2008), without the need to invest in expensive roads and railways (Perrett, 2008). 
Unveiled at the Beijing Air Show in 2001 (Eriksson, 2010) the ARJ21 was formally approved by the Chinese government in June 2002 with a CNY 5 billion $(\$ 600 \mathrm{~m})$ investment (Sobie, 2003). From the start the ARJ21 was a derivative design (Smith and Rogers, 2004) based on the McDonnell-Douglas MD-80/90 (Butterworth-Hayes, 2010), to which it bears a striking resemblance (Vertesy and Szirmai, 2010). Utilising tooling and jigs provided by McDonnell-Douglas as part of the earlier collaborative programme (Francis, 2007), the ARJ21 has an identical fuselage cross-section, nose section and tail. The first phase of the ARJ21 programme was directed to the development of the baseline passenger version of the aircraft designed to carry 85-90 passengers and with a range of 2000 nautical miles (Doyle, 2002). Given that it was targeted at the domestic market (Goldstein, 2006), relatively modest sales goals were set for the ARJ21, with total sales forecast as 500 over a 20 year period.

Table 2 Comac ARJ21 ancillary systems

\begin{tabular}{lcc}
\hline Supplier & Country & System \\
\hline General Electric & USA & CF34-10A turbofans \\
Rockwell Collins & USA & ProLine 21 avionics \\
Honeywell & USA & Flight control system \\
Eaton Corporation & USA & Cockpit systems \\
Goodrich & USA & Brakes and tyres \\
Parker Hannifin & USA & Hydraulic systems \\
Hamilton Sundstrand & USA & Auxiliary power unit \\
Leibherr Aerospace & Germany & Landing gear \\
Sagem & France & Flight deck control system \\
Meggitt & UK & Engine control system \\
Smiths & UK & Thrust reversal actuator \\
\hline
\end{tabular}

A key feature of the project was the use of a network of Western suppliers employed to provide the major sub-systems of the aircraft (i.e., engines, landing gear and avionics) on an 'off-the-shelf' basis (Yeo, 2011b). Several US-based multinationals (see Table 2) such as General Electric, Rockwell Collins, Honeywell and Hamilton Sundstrand were involved as systems suppliers. In addition the Ukrainian design bureau, Antonov, designed and tested the new supercritical wing and the Canadian firm Bombardier provided technical assistance (Vertesy and Smirzai, 2010). In total the network of suppliers was estimated to be responsible for some $60-70 \%$ of the value of the aircraft [Francis, (2006), p.65]. Utilising a 'network' development model in this way enabled Comac to tap into the global technological and investment capacities available in the West. This significantly reduced the technological demands on Comac, allowing it to concentrate on developing its systems integration capability, the most critical element in terms of the expertise required to develop a modern airliner. Potentially it also reduced both the development cost and the lead time to market. Supplier selection went smoothly and was completed by 2003.

When the project was given the formal go-ahead in 2002 it was envisaged that the aircraft's maiden flight would be in 2006 with entry into service a year later in 2007 (Doyle, 2002). However, the project encountered significant delays at the design stage. Regulators required the fuselage exit doors to be moved further back in order to facilitate 
easier and faster evacuation in the event of an emergency. Unfortunately re-positioning the doors created a further problem, as it meant that they were too close to the aircraft's fuselage mounted engines. This necessitated stretching the fuselage by a metre to create more space between the doors and the engines. This also provided space for an extra row of seats (Francis, 2006). As a result of this and a number of other required design changes, the entry into service date slipped by two years to 2009.

The first metal was cut in 2004 and parts manufacture started in February 2006. Roll out of the first completed airframe at Dachang Airport in Shanghai took place in December 2007. This was followed almost a year later by the aircraft's maiden flight, which had by now been postponed several times (Williams, 2009), in late November 2008 (Francis, 2008). As Table 3 shows sales had by then reached 200 aircraft, although the programme was already three years behind schedule (Rabinovitch, 2012).

The flight test programme involved extensive testing using four aircraft to prepare it for airworthiness certification not only with the Chinese authorities, but the FAA in the US as well. However the test programme did not go smoothly. Airworthiness certification was repeatedly delayed by serious setbacks. In November 2010 a wing cracked in testing (Rabinovitch, 2012). This led the Civil Aviation Administration of China (CAAC) to limit the aircraft's flight envelope for the test programme, pushing the entry into service date back to late 2011. Problems were encountered with the wiring and the integration of the avionics systems (Toh, 2012), which further delayed the programme.

However in April 2011 a major project milestone was reached when the aircraft finally completed static testing successfully (Yeo, 2011a). By mid-2012, significant progress had been made although the development programme had suffered further slippage. The ARJ21 successfully completed multiple take-off and landing tests required for airworthiness certification (Rabinovitch, 2012). At this point, He Dongfeng, Comac's president, announced that after ten years of development, the ARJ21 had at last entered the final phase required to complete airworthiness certification. However full regulatory approval was not now expected until 2013 with first deliveries of the aircraft to airlines expected early in 2014 (Toh, 2012), more than six years later than originally planned.

\section{Discussion: the ARJ21 programme in perspective}

A recent appraisal of the ARJ21 programme described it as having 'stumbled at the starting blocks' [Rabinovitch, (2012), p.2], a reference to the fact that a number of short-comings and problems had become evident during the course of its lengthy development programme. The first of these was the successive delays and postponements, which had occurred in the ARJ21 programme, resulting in the programme being some six years behind schedule. As the case study indicates, this reflected a combination of factors including, an over-ambitious initial schedule, design problems, test failures and certification problems, which taken together resulted in successive postponements in the programme.

Secondly, a number of commentators had also highlighted weaknesses in the programme itself, in particular the fact that the ARJ21 was, 'lacking the technical strengths expected of a new product' [Perrett, (2008), p.24], or as Richard Aboulafia of the aerospace consultants Teal Group put it the aircraft was, 'stunningly obsolete' [Yeo, (2011b), p.34]. This was a reference to the fact that the ARJ21, was a derivative of the McDonnell-Douglas MD80/90 of the 1980s, made little or no use of lightweight 
composite materials, and was not equipped with the latest fuel efficient engines As a result it was relatively old-fashioned and overweight and offered comparatively poor performance in terms of fuel economy, compared to the new generation of regional jets being developed, and either in service or about to enter service at about the same time as the ARJ21. As Cliff et al. (2011, p.116) note in relation to the ARJ21, "thus even before it reaches production whether or not it can compete with existing Embrear and Bombardier regional jets is questionable ..... in a market in which fuel efficiency is a key characteristic, it is not clear why airlines would choose to forgo brands with proven safety and reliability records to purchase an unproven and less efficient aircraft”.

Table 3 Comac ARJ21 orders 2003-2008

\begin{tabular}{llcc}
\hline Airline & Date & Country & Quantity \\
\hline Shanghai Airlines & 2003 & China & 5 \\
Shandong Airlines & 2003 & China & 10 \\
Shenzhen Financial Leasing & 2003 & China & 20 \\
Shanghai Financial Leasing & 2003 & China & 30 \\
Xiamen Airlines & 2004 & China & 6 \\
Kunpeng Airlines & 2007 & China & 100 \\
Lao Airlines & 2007 & Laos & 2 \\
GECAS & 2008 & US & 5 \\
Joy Air & 2008 & China & 50 \\
\hline Total & & & 228 \\
\hline
\end{tabular}

Source: Flight International (various)

A third short-coming was the relative modest sales that had been achieved. As Table 3 shows by 2008 total orders for the 90 seat regional jet stood at a little over 200. Even then they were almost exclusively domestic orders from China's smaller short haul operators, the only foreign order being from Lao Airlines. Not only had the ARJ21 failed to achieve any sales to Western airlines, none of China's 'big three' national carriers, Air China, China Eastern Airlines and China Southern Airlines had committed to the aircraft. As with China's previous attempts at developing small commuter aircraft, often based on Russian designs, the ARJ21 had little or no relevance outside China.

Table 4 New 100 seat Regional Jets

\begin{tabular}{lccccc}
\hline Manufacturer & Aircraft & Size & Engines & Country & Planned EIS \\
\hline Comac & ARJ21 & $75-96$ & GE CF34 & China & 2011 \\
Mitsubishi & MRJ-70 & $70-96$ & PW1000G & Japan & 2014 \\
Embraer & E-170/190 & $70-120$ & GE CF34 & Brazil & 2004 \\
Sukhoi & Superjet 100 & $78-98$ & SaM146 & Russia & 2010 \\
Bombardier & C series & $110-149$ & PW1000G & Canada & 2015 \\
\hline
\end{tabular}

Finally, the ARJ21 appeared, in part as a result of the lengthy period taken to develop the aircraft, to have been overtaken by new competitor aircraft in the regional jet sector even before it entered service. As Table 4 shows these new competitors include the Japanese Mitsubishi MRJ70, the Russian Sukhoi Superjet 100, and the Canadian Bombardier C 
series. These new aircraft are advanced designs that make extensive use of lightweight composite materials and are equipped with new more efficient engines such as the Pratt and Whitney PW1000G geared turbofan engine. With their advanced designs, these newcomers offer significantly better performance than the ARJ21 (Perrett, 2008), in the case of the Mitsubishi MRJ as much as a $20 \%$ lower fuel burn. This has enabled all three aircraft to rack up significant orders from genuine blue chip non-domestic customers, including, in the case of the Mitsubishi MRJ, an order from America's Trans States Holdings for 100 aircraft (Kingsley-Jones, 2009).

However despite these short-comings it would be a mistake to rush to write-off the ARJ21 programme. For a start it is the first commercial jet to be designed and built in Asia, something that several countries have attempted to do but in which as yet only the Chinese have succeeded.

In relation to the specific criticisms of the programme that have been outlined, it should be noted that although a six-year delay is a serious setback, delays in the development of new aircraft are not unusual. Both Boeing and Airbus have suffered lengthy and very costly delays with their most recent new aircraft projects, namely the Boeing 787 Dreamliner and the Airbus A380 Superjumbo. Similarly the claim that the ARJ21 is out-dated, old fashioned and lacking in new technology could also be levelled at Embraer and Bombardier. Their first regional jets, like the ARJ21, were 'derivative designs' [Smith and Rogers, (2004), p.522] based on existing aircraft but equipped with new engines and other up-graded systems to make them suitable for the regional jet market. As newcomers to the regional jet market these derivative designs actually proved very effective in enabling them to break into a market occupied by established airliner manufacturers.

Similarly the lack of overseas orders, while undoubtedly disappointing, reflects the fact that the ARJ21 was planned primarily as a regional jet for the domestic Chinese market. Indeed it was designed to meet the very specific requirements of this market, like being able to operate from airports in the more remote and mountainous western regions of China such as Tibet, where conditions are particularly demanding.

However the ARJ21 was above all intended primarily as an interim design. According to Perrett (2007) the Chinese authorities have always taken a long term perspective in terms of catch-up in the commercial aerospace industry. Perrett (2007) notes how this typically involves a deliberate, step-by-step learning process reminiscent of former Chinese leader Deng Xiaoping who advocated, 'cross the river by feeling the stones'. Thus each step is based on experience from the previous one which in turn yields more experience for the next step. Hence the three stage process to enter commercial aerospace first embarked upon back in the 1980s, in which the ARJ21 project is but one stepping stone that will ultimately lead to China becoming a serious player in the global commercial aerospace industry.

With this in mind it is important to note that the next stepping stone is already in place in the form of the Comac C919 180 seat, narrow body airliner launched in 2008. Due to make its first flight in 2014 (Yeo, 2010), this aircraft is the final stage of the three stage process initiated by the Chinese authorities in the 1980s. The Comac C919 will not only merely compete head-on with the Boeing and Airbus airliners, it is a modern design equipped with state-of-the-art CFM International Leap 1-C turbofan engines currently under development by the General Electric-Snecma joint venture, and even though still at an early stage of development, it has already attracted the attention of the world's 
airlines, with the Irish low cost carrier, Ryanair and British Airways having signed an agreement with Comac (Milmo, 2011).

Hence the short-comings of the ARJ21 programme have to be set in the context of its primary role as a learning vehicle designed, as part of the three step plan initiated in the 1980s, to facilitate the development of a modern narrow body airliner in the form of the Comac C919 that will compete directly with Boeing and Airbus. To this end Bédier et al. (2008) note that whether or not the C919 proves an effective competitor for Boeing and Airbus, is likely to depend on the extent to which the ARJ21 programme has enabled the Chinese, not merely to design and develop a modern commercial airliner to full Western standards, but also to accumulate the necessary programme management skills to coordinate many subcontractors and system suppliers, and put in place appropriate aftermarket support capabilities and facilities.

Against this background, the delays and postponements, the lack of international sales and the reliance on current technology, while disappointing and attracting the ire of some Western commentators, may not in the long term be that significant, since the main purpose of the ARJ21 is to enable the Chinese to learn and accumulate the necessary capabilities to compete with Boeing and Airbus.

\section{Conclusions}

This study set out to answer two questions:

1 What have been the main changes in the SSI for commercial aerospace?

2 What are the implications of these changes for latecomer nations?

The evidence presented here shows that the SSI has not merely changed in the last 20 years, it has been transformed through a process of co-evolution. While the airframe manufacturers like Boeing and Airbus still dominate the sector in terms of overall sales of commercial airliners, co-evolution of the three elements of the SSI, actors, knowledge base and institutions, has resulted in a very different process of new product development emerging.

This is very clearly in evidence with the ARJ21 programme. Unlike previous commercial aerospace projects in China, the ARJ21 relies on a network of strategic suppliers who have worked with Comac to provide the major sub-systems for the aircraft. These suppliers are from the West, chiefly the USA, and they are all major multinational corporations in their own right. As the case study shows many of these sub-systems (e.g., engines, landing gear and avionics) are provided on an 'off-the-shelf' basis rather than being developed specifically for this application. The significance of this network of suppliers is evident in the foreign content of the ARJ21, which has been estimated to be some $60-70 \%$ of its total value. Utilising this network approach to new product development has enabled Comac to become the first Asian aerospace manufacturer to develop a commercial airliner, something that many others have tried to do in the past but failed. Hence one may conclude that in the aerospace industry the old model of new product development where vertically integrated firms are the key actors within the SSI carrying out all the principal development functions, has evolved into a network SSI, where new commercial airliners are developed in close collaboration with strategic suppliers who account for the development and manufacture of up to two thirds of a 
modern airliner, and the Chinese have endeavoured to take advantage of this evolutionary change with the ARJ21 programme.

What are the implications for latecomer nations keen to catch-up and become significant players within the global aerospace industry? On the face of it the case of the ARJ21 suggests that the move to a network SSI makes it significantly easier for latecomer nations to catch-up. No longer is it necessary for one country to undertake the development of the entire aircraft, instead it is possible to work with strategic suppliers who have the experience and expertise to provide many of the necessary systems and sub-systems, thereby reducing uncertainty and the scale of the development task. Not only that, the case of the ARJ21 also shows the value of a staged approach to catch-up, where there is scope for extensive learning at each step or stage in the catch-up process. Under these circumstances catch-up is easier because new entrants can focus on key tasks like systems integration and the provision of appropriate product support.

However, it would be a mistake to jump to this conclusion on the evidence of the ARJ21 programme. The emergence of a new SSI may indeed make the task of catch-up, while still a long and difficult process, a significantly less daunting one for latecomer nations. But, China is in many respects a special case. What is special is what McGuire (2011, p.2) describes as, 'the immense promise of its internal air-travel market'. China is the second largest national air travel market in the world behind the USA (Cliff et al., 2011). In 2007 China's airlines booked more than 230 billion revenue passenger kilometres (RPK). Although this was only $20 \%$ of the traffic carried by US airlines it was still more traffic than that carried by other leading developed nations like Japan and Germany (Cliff et al., 2011). Not only that, China by virtue of its land area, population and growth prospects, represents huge latent demand (Hanlon, 2007). According to Boeing (2012) over the next 20 years GDP is likely to grow annually at 6.5\%, with air traffic growing at $7 \%$ as a new middle class emerges. As Table 5 shows to accommodate this the country's airline fleet will need to treble in size between 2012 and 2031, with some 5,260 new aircraft valued at $\$ 670$ billion required. In time China may well become the world's largest aircraft market.

Table 5 Chinese Commercial Airliner Market 2012-2031

\begin{tabular}{lcccc}
\hline Aircraft & 2011 fleet & 2031 fleet & New aircraft & $\%$ \\
\hline Large & 80 & 140 & 110 & $2.0 \%$ \\
Twin aisle & 280 & 1,310 & 1,190 & $23.0 \%$ \\
Single aisle & 1,490 & 4,220 & 3,650 & $69.0 \%$ \\
Regional & 60 & 310 & 310 & $6.0 \%$ \\
\hline Total & 1,910 & 5,980 & 5,260 & $100.0 \%$ \\
\hline
\end{tabular}

Source: Boeing (2012)

A domestic market on this scale is something that no other latecomer nation can approach. Hence while the ARJ21 programme may demonstrate the potential of the new network SSI that is now found in the aerospace industry to enable latecomer nations to catch-up, it seems likely that the phenomenon of catch-up will be limited in its applications. It may well enable latecomer nations like Brazil and Japan to establish a presence as players in the commercial aerospace industry, but this is likely to be as niche players, supplying smaller aircraft like regional jets or as suppliers of specialist systems, only China by virtue of its huge domestic market seems likely to offer a serious challenge 
to the current duopoly of Boeing and Airbus. And on the evidence of the time taken to develop the ARJ21 that point is still a decade off. However, when it does arrive, the role of the ARJ21 as a 'stepping stone' that enabled the Chinese to link up with Western suppliers, leverage technical knowledge, and learn the commercial aerospace business may then finally become apparent.

\section{References}

Anderlini, J. (2008) ‘A nation’s hopes rest on a Flying Phoenix’, Financial Times, 14th July, p.4, Aerospace Special Report, London.

Andersen, P.A. (2008) China's Growing Market for Large Aircraft, Office of Industries Working Paper ID-18,US International Trade Commission, Washington, DC.

Balut, S.J., McNicol, D.L., Nelson, J.R., Harman, B.R. and Holder, S.G. (2008) Visit to China's ARJ21 Aircraft Manufacturing Facility, Institute for Defense Analyses, Alexandria, VA.

Bédier, C., Vancauwenberghe, M. and Van Sintern, W. (2008) 'The growing role of emerging markets in aerospace', The McKinsey Quarterly, April, pp.1-13.

Benzler, G. and Wink, R (2010) 'From agglomerations to technology and knowledge driven clusters: aeronautics cluster policies in Europe', International Journal of Technology Management, Vol. 50, Nos. 3/4, pp.318-336.

Bitzinger, R.A. (2010) China: Leading the Re-Birth of Asia's Commercial Aircraft Industry, RSIS Commentaries, Nanyang Technological University, Singapore.

Boeing (2012) Current Market Outlook 2012-2031 [online] http://www.Boeing.com/commercial/ cmo/pdf/Boeing_Current_Market_Outlook_2012.pdf (accessed 3 June 2013).

Breschi, S. and Malerba, F. (1997) 'Sectoral innovation systems: technological regimes, Schumpeterian dynamics and spatial boundaries', in Edquist, C. (Ed.): Systems of Innovation: Technologies, Institutions and Organisations, pp.130-156, Pinter.

Butterworth-Hayes, P. (2010) 'China’s march to aerospace autonomy', Aerospace America, February, pp.24-31.

Cantle, K. (2008) 'The path to the dream', Air Transport World, May, Vol. 45, No. 5, pp.64-66.

Cliff, R., Ohlandt, C.J.R. and Yang, D. (2011) Ready for Takeoff: China's Advancing Aerospace Industry, RAND Corporation, Santa Monica, CA.

Cooke, P. and Ehret, O. (2009) 'Proximity and procurement: a study of agglomeration in the Welsh Aerospace Industry', European Planning Studies, Vol. 17, No. 4, pp.549-567.

Dicken, P. (2011) Global Shift: Mapping the Changing Contours of the World Economy, 6th ed., Sage Publications, London.

Dougan, M. (2002) A Political Economy Analysis of China's Aviation Industry, Routledge, London.

Doyle, A. (2002) 'Lure of the east', Flight International, 29th October-4th November, Vol. 162, No. 4855, pp.42-47.

Dunne, P. (1999) 'The globalisation of arms production and trade: implications for the UK economy', CAAT 25th Anniversary Public Lecture, 9th November, London.

Edquist, C. (2001) 'The systems of innovation approach and innovation policy: an account of the state of the art', DRUID Conference, 12th-15th June, Aalborg, Denmark.

Edquist, C. and Johnson, B. (1997) 'Institutions and organisations in systems of innovation', in Edquist, C. (Ed.): Systems of Innovation: Technologies, Institutions and Organizations, Routledge, London.

Ehret, O. and Cooke, P. (2010) 'Conceptualizing aerospace outsourcing: airbus UK and the lean supply approach', International Journal of Technology Management, Vol. 50, Nos. 3/4, pp.300-317. 
Endres, G. (2007) 'A fine balance', Flight International, 30th October-5th November, Vol. 172, No. 5111, pp.24-37.

Engel, J.A. (2007) Cold War at 30,000 Feet: The Anglo-American Fight for Aviation Supremacy, Harvard University Press, Cambridge, MA.

Eriksson, S. (2010) 'China's aircraft industry: collaboration and technology transfer - the case of airbus', International Journal of Technology Transfer and Commercialisation, Vol. 9, No. 4, pp.306-325.

Figuieredo, P., Gutenberg, S. and Sbragia, R. (2008) 'Risk-sharing partnerships with suppliers: the case of embraer', Journal of Technology Management and Innovation, Vol. 3, No. 1, pp.27-37.

Francis, L. (2006) 'Chinese turn', Flight International, 14th-20th February, Vol. 169, No. 5023, pp.64-66.

Francis, L. (2007) 'Trunkliner techniques return for ARJ21', Flight International, 24th-30th August, Vol. 172, No. 5101, p.37.

Francis, L. (2008) 'ARJ21 regional jet rolls out in Shanghai', Flight International, 8th-14th January, Vol. 173, No. 5120, p.8.

Geels, F.W. (2004) 'From sectoral systems of innovation to socio-technical systems: insights about dynamics and change from sociology and institutional theory', Research Policy, Vol. 33, Nos. 6-7, pp.897-920.

Goldstein, A. (2002) 'Embraer: from national champion to global player’, CEPAL Review, August, Vol. 77, pp.97-115.

Goldstein, A. (2006) 'The political economy of industrial policy in China: the case of aircraft manufacturing', Journal of Chinese Economic and Business Studies, Vol. 4, No. 3, pp.259-273.

Goldstein, A. (2008) 'A Latin American global player goes to Asia: Embraer in China', International Journal of Technology and Globalisation, Vol. 4, No. 1, pp.56-69.

Goldstein, A. and Le Blanc, G. (2003) 'High-tech clusters in the north and in the south: a comparison between Montreal and San José dos Campos', EADI Workshop: Clusters and the Global Value Chain in the North and in the Third World, 30th-31st October, Università degli Studi del Piemonte Orientale, Novarà, Italy.

Hanlon, P. (2007) Global Airlines: Competition in a Transnational Industry, 3rd ed., Butterworth-Heinemann, Oxford.

Hekkert, M.P., Suurs, R.A.A., Negro, S.O., Kuhlman, S. and Smits, R.E.H.M. (2007) 'Functions of innovation systems: a new approach for technical change', Technological Forecasting and Social Change, Vol. 74, No. 4, pp.413-432.

Heppenheimer, T.A. (1995) Turbulent Skies: The History of Commercial Aviation, John Wiley and Sons, New York.

Heymann, H. (1975) China's Approach to Technology Acquisition Part 1: The Aircraft Industry, R-1573-ARPA, Rand Corporation, Santa Monica, CA.

Hooker, S. (1984) Not Much of An Engineer, Airlife Publishing, Shrewsbury.

Johnson, B.D. (1992) China's Aerospace Industry: Technology, Funding and Modernization, MA Thesis, University of Hawaii, Manoa, HI.

Kimura, S. (2007) The Challenges of Late Industrialization: The Global Economy and the Japanese Commercial Aircraft Industry, Palgrave Macmillan, Basingstoke.

Kingsley-Jones, M. (2009) 'US deal boosts MRJ status', Flight International, 13th-19th October, Vol. 176, No. 5210, p.12.

Langeweische, W. (2009) Fly by Wire: The Geese, The Glide, The 'Miracle' on the Hudson, Penguin Books, London.

Lawrence, P.K. and Thornton, D. (2005) Deep Stall: The Turbulent Story of Boeing Commercial Airplanes, Ashgate, Farnham.

Lewin, A.Y. and Volderba, H.W. (1999) 'A framework for research on strategy and new organisational forms’, Organization Science, Vol. 10, No. 5, pp.519-534. 
Lewis, P. (1995a) 'Competition for 100 seat regional jet slot increases', Flight International, 13th-19th December, Vol. 148, No. 4502, p10.

Lewis, P. (1995b) 'Indecision rules in Asia', Flight International, 25th-31st November, Vol. 148, No. 4499, p.22.

Lewis, P. (1996) 'China and South Korea wrangle over AE100', Flight International, 17th-23rd January, Vol. 149, No. 4506, p.5.

Lewis, P. (1997) 'Time out in Asia', Flight International, 5th-11th November, Vol. 152, No. 4599, pp.38-40.

Lorrell, M., Lowell, J., Kennedy, M. and Levaux, H. (2000) Cheaper Faster Better? Commercial Approaches to Weapons Acquisition, Rand Corporation, Santa Monica, CA.

MacPherson, A. and Pritchard, D. (2007) 'Boeing's diffusion of commercial aircraft technology to Japan: surrendering the US industry for foreign financial support', Journal of Labor Research, Vol. 28, No. 3, pp.552-566.

Malerba, F. (2004) 'Sectoral systems of innovation: basic concepts', in Malerba, F. (Ed.): Sectoral Systems of Innovation: Concepts, Issues and Analyses of Six Major Sectors in Europe, Cambridge University Press, Cambridge.

Malerba, F. (2005) 'Sectoral systems: how and why innovation differs across sectors', in Fageberg, J., Mowery, D.C. and Nelson, R.R. (Eds.): The Oxford Handbook of Innovation, Oxford University Press, Oxford.

Malerba, F. (2006) 'Catch-up in different sector systems: some introductory remarks, innovation systems for competitiveness and shared prosperity in developing countries', Globelics Conference 2006, 4-7 October, Trivandrum, Kerala, India.

Malerba, F. and Mani, S. (2009) Sectoral Systems of Innovation and Production in Developing Countries: Actors, Structure and Evolution, Edward Elgar, Cheltenham.

Marques, R.A. and de Olveira, L.G. (2009) Sectoral system of innovation in Brazil: reflections about the accumulation of technological capabilities in the aeronautical sector (1990-2002)', in Malerba, F. and Mani, S. (Eds.): Sectoral Systems of Innovation and Production in Developing Countries: Actors, Structure and Evolution, Edward Elgar, Cheltenham.

McGuire, S. (1999) 'Sectoral innovation patterns and the rise of new competitors: the case of civil aerospace in Asia', Industry and Innovation, Vol. 6, No. 2, pp.153-170.

McGuire, S. (2011) The Changing Landscape of the Aircraft Industry, July, Chatham House Briefing Paper, IE WIT 2011/12, Chatham House, London.

McGuire, S., Fai, F. and Ozaki, T. (2010) 'Path dependence as a political construct, the disruptive influence of technology and Japanese aerospace’, International Journal of Technology Management, Vol. 50, Nos. 3/4, pp.367-379.

Milmo, D. (2011) 'Ryaniar gets on board with Chinese rival to Boeing', The Guardian, 26th June, p.22.

Newhouse, J. (2007) Boeing versus Airbus: The Inside Story of the Greatest International Competition in Business, Alfred A. Knopf, New York.

Nolan, P. and Zhang, J. (2002) 'The challenge of globalization for large Chinese firms', World Development, Vol. 30, No. 12, pp.2089-2107.

Nolan, P. and Zhang, J. (2003) 'Globalization challenge for large firms from developing countries: China's oil and aerospace industries', European Management Journal, Vol. 21, No. 3, pp.285-299.

Nolan, P., Zhang, J. and Liu, C. (2008) 'The global business revolution, the cascade effect, and the challenge for firms from developing countries', Cambridge Journal of Economics, Vol. 32, No. 1, pp.29-47.

North, D.C. (1990) Institutions, Institutional Change and Economic Performance, Cambridge University Press, Cambridge.

Perrett, B. (2007) 'China learning how to develop, support airliners with ARJ21', Aviation Week \& Space Technology, 16th September, Vol. 167, No. 11, pp.76-78. 
Perrett, B. (2008) 'China’s challenge’, Aviation Week \& Space Technology, 7th April, Vol. 168, No. 14, pp.24-25.

Pritchard, D. and MacPherson, A. (2007) 'Strategic destruction of the western commercial aircraft sector: implications of systems integration and international risk-sharing business models', The Aeronautical Journal, May, Vol. 111, No. 1119, pp.327-334.

Rabinovitch, S. (2012) 'China offers a serious challenge to Boeing and Airbus', Financial Times, 9th July, p.2, Aerospace Special Report.

Rogers, E. (1996) Flying High: The Story of Boeing and the Rise of the Jetliner Industry, The Atlantic Monthly Press, New York.

Sabbagh, K. (1996) 21st Century Jet: Making of the Boeing 777, Pan Books, London.

Sampson, A. (1984) Empires of the Sky: The Politics, Contests and Cartels of World Airlines, Random House, New York.

Samuels, R.J. (1994) Rich Nation Strong Army: National Security and the Technological Transformation of Japan, Cornell University Press, Ithaca, NY.

Smith, D.J. (2003) 'Strategic alliances and competitive strategy: the case of BMW Rolls-Royce GmbH', European Business Review, Vol. 15, No. 4, pp.262-276.

Smith, D.J. and Rogers, M.F. (2004) 'Technology strategy and innovation: the use of derivative strategies in the aerospace industry', Technology Analysis and Strategic Management, Vol. 16, No. 4, pp.509-527.

Smith, D.J. and Tranfield, D. (2005) 'Talented suppliers? Strategic change and innovation in the UK aerospace industry’, R\&D Management, Vol. 35, No. 1, pp.37-49.

Sobie, B. (2003) 'Lure of the east', Flight International, 29th October-4th November, Vol. 164, No. 4907, pp.42-47.

Steenhuis, H.J. and de Bruijn, E.J. (2004) 'High technology in developing countries: analysis of technology strategy, technology transfer and success factors in the aircraft industry', $13^{\text {th }}$ International Conference on Management of Technology (IAMONT), 3rd-7th April, Washington, DC.

Steenhuis, H.J., De Bruijn, E.J. and Heerkens, H. (2007) 'Technology transfer and catch-up', International Journal of Technology Transfer and Commercialisation, Vol. 6, Nos. 2-4, pp.250-278.

Sweeney, P. (2008) Flying Without Succeeding? Assessing the Future of the Civil Aviation Manufacturing Sector in the People's Republic of China, MA dissertation, MA China Studies Program, Henry M. Jackson School of International Studies, University of Washington, Seattle, WA.

Todd, D. and Simpson, J. (1985) The World Aircraft Industry, Croom Helm, London.

Toh, M. (2012) 'Is China cracking?’, Flight International, 3rd-9th July, Vol. 182, No. 5348, pp.86-88.

Vertesy, D. and Szirmai, A. (2010) 'Interrupted innovation: innovation system dynamics in latecomer aerospace industries', 8th Globelics International Conference: Making Innovation Work for Society: Linking, Leveraging and Learning, 1-3 November, University of Malaya, Kuala Lumpur, Malaysia.

Williams, A. (2009) Contemporary Issues Shaping China's Civil Aviation Policy: Balancing International with Domestic Priorities, Ashgate, Farnham.

Yeo, G-L. (2010) 'China’s big challenge', Flight International, 9th-15th November, Vol. 178, No. 5264, pp.40-41.

Yeo, G-L. (2011a) 'Comac steps up ARJ21 flight testing programme’, Flight International, 3rd-9th May, Vol. 179, No. 8289, p.15.

Yeo, G-L. (2011b) 'Symbol of success?', Flight International, 8th-14th March, Vol. 179, No. 5282, pp.34-35.

Zhang, M., Macpherson, A. and Jones, O. (2006) 'Conceptualizing the learning process in SMEs: improving innovation through external orientation’, International Small Business Journal, Vol. 24, No. 3, pp.299-323. 